\title{
The Influence of Hotel Employees' Perception of CSR on Organizational Commitment: The Moderating Role of Job Level
}

\author{
Kum-Sik Oh ${ }^{1}$, Juyeon Rachel Han ${ }^{2}$ and So Ra Park ${ }^{3, *(D)}$ \\ 1 Division of Global \& Interdisciplinary Studies, Pukyong National University, Busan 48513, Korea; \\ ksoh@pknu.ac.kr \\ 2 Department of Hotel Management, Cheju Halla University, Jeju 63092, Korea; Rhan@chu.ac.kr \\ 3 Department of Tourism Management, Cheju Halla University, Jeju 63092, Korea \\ * Correspondence: doorae0207@chu.ac.kr
}

check for updates

Citation: Oh, K.-S.; Han, J.R.; Park, S.R. The Influence of Hotel Employees' Perception of CSR on Organizational Commitment: The Moderating Role of Job Level. Sustainability 2021, 13, 12625. https:/ / doi.org/10.3390/su132212625

Academic Editor: David K. Ding

Received: 28 October 2021

Accepted: 12 November 2021

Published: 15 November 2021

Publisher's Note: MDPI stays neutral with regard to jurisdictional claims in published maps and institutional affiliations.

Copyright: (c) 2021 by the authors. Licensee MDPI, Basel, Switzerland. This article is an open access article distributed under the terms and conditions of the Creative Commons Attribution (CC BY) license (https:// creativecommons.org/licenses/by/ $4.0 /)$.

\begin{abstract}
This study attempts to investigate the relationships among Korean hotel employees' perception of Corporate Social Responsibility (CSR), their intrinsic motivations, and their organizational commitment (OC). The mediating effect of intrinsic motivation on the relationship between employees' perception of customer- and employee-related CSR and OC is explored, and the moderating role of job level on the relationship between CSR perceptions and intrinsic motivation is tested. The data were collected via online survey, and the Hayes' Process macro was used as an analysis tool. We found that (1) both types of CSR perceptions are important in creating intrinsic motivation and OC, (2) intrinsic motivation enhances OC, and (3) job level moderates the link between employee CSR perceptions and intrinsic motivation positively. Interestingly, we found that when customer-related CSR or employee-related CSR is high, the level of intrinsic motivation will significantly differ between managerial and non-managerial employees. This study's results will contribute to the current literature on CSR, and will aid human resources departments that are considering CSR practices as a means to enhancing employee intrinsic motivation and OC.
\end{abstract}

Keywords: CSR perception; organizational commitment; intrinsic motivation; moderating effect

\section{Introduction}

The issue of Corporate Social Responsibility (CSR) has been receiving a great deal of attention in many academic areas and from the business media during the last two decades [1-3]. The reason for this is that CSR is regarded as a method of building an organizational reputation and enhancing the corporate image as well as providing advantages to both companies and their stakeholders [4]. Companies have gradually recognized the significance of CSR, and are attempting to maintain a balance among social, environmental, and economic activities in their businesses [5]. CSR tends to be considered along with responsible management to ensure sustainable growth [6]. Moreover, organizations involved in CSR activities are building positive corporate reputations, enhancing values and profitability, managing risks and costs, and promoting customer loyalty [7-10]. CSR activities are also implemented when faced with severe competition from new entrants to the market in service industries such as hotels [11]. Such activities provide various benefits to hotels, such as customer loyalty and a positive brand image, resulting in revisits and recommendations [12]. Thus, CSR activities are important to the stakeholders as well as the organizations $[13,14]$.

Due to the competitiveness of the hotel industry, customer loyalty is critical [15]. Employees interact directly with customers, and those interactions influence customer loyalty [16], so attracting and maintaining quality employees is critical for competitiveness within the industry. Therefore, given the labor-intensive nature of the hotel business, employees should be considered a key stakeholder along with customers [13]. However, the employee turnover rate in the hospitality industry is exceptionally high within the retail 
sector [17], making it harder for the industry to maintain a reliable workforce. CSR activities have been adopted by many hotels in order to maintain their competitive advantage [13], and companies have begun to promote their own superior CSR performance to remain attractive to their employees [18]. Research on employee-related CSR has been receiving less attention compared to the sizable amount of customer-related CSR research. Considering CSR's role in the hotel industry [19], it is critical to understand how employees' perception of CSR can affect their attitudes toward their employers [17].

Despite increasing concerns over CSR and the need to understand CSR perceptions in employees, not much research has been conducted on the relationships between CSR and employee attitudes and behaviors [20]. In particular, the relationship between employee CSR perception and organizational commitment (OC), and the underlying process leading to $\mathrm{OC}$, are even less studied areas [21]. Our research is designed to investigate the relationship between employee CSR perception and OC, and the role of intrinsic motivation as a mediator between them. Motivation is closely related to the sensory formation process directly controlling each member's perception and behavior [22]. How employees respond to a company's CSR, and their willingness to contribute to the organization, may vary depending on motivational factors [23]. In some organizational studies, job level was used as a factor influencing employee attitudes and performance. For example, in a corporate setting, managers and non-managers were found to take on expected and assumed behaviors and beliefs appropriate to their positions within the organization [24], and thus, work-related performance and attitudes could depend on employee position.

To further understand employees' perception of CSR, our research on the Korean hotel industry focuses on the relationships among employees' perception of CSR, their intrinsic motivations, as well as OC. Using stakeholder theory as a theoretical background, this study investigates (1) the relationship between the perceptions of hotel employee-related and customer-related CSR and their intrinsic motivations, (2) the relationship between intrinsic motivation and OC, (3) the intermediate role of intrinsic motivation between CSR perception and OC, and (4) the moderating effect of an employee's job level on the relationship between CSR perception and intrinsic motivation. By doing so, this study attempts to contribute to the existing CSR literature by finding out the underlying influence of South Korean hotel employees' perception of CSR on their own OC.

This study contributes to extending our understanding of the current CSR literature by investigating the influence of employees' CSR perception on intrinsic motivation and OC using stakeholder theory. By investigating how this phenomenon varies depending on the job level of employees, this study can contribute to help hotels better manage their human resources and therefore strengthen their competitiveness. This investigation has a practical significance for the highly competitive Korean hotel industry. This paper is organized as follows. Starting with the introduction, Section 2 provides the background theoretical development and hypotheses of the research, and the methodology of the research including the analysis will follow. Then, a discussion of our findings is presented in Section 4, and the paper ends with the contributions and limitations of our study.

\section{Theoretical Development and Hypotheses}

Stakeholders are referred to as "those groups without whose support the organization would cease to exist," and Freeman defined them as "those groups who can affect or are affected by the achievement of an organization's purpose" [25]. Stakeholders are therefore essential participants in a company's existence, who play three roles for corporate social performance. Stakeholders are corporate goal-setters who have concrete expectations of performance. Those expectations help the corporation with its CSR direction. As a second role, stakeholders experience the consequences of corporate behavior, which is a passive role. Their third role is as appraisers of corporate behavior, and to fulfill that role, they evaluate their company-related experience and the experience of other stakeholders. Stakeholder theory was initially used in analyzing the external environment and determining organizational capabilities for corporate planning or policymaking [23]. However, stake- 
holder theory later became the backbone theory supporting the corporate pro-stakeholder direction. CSR activities have been mentioned with organizational stakeholders including employees, customers, suppliers, and other communities.

A company's CSR activity is defined as "the managerial obligation to take action to protect and improve both the welfare of society as a whole and the interest of the organization" [26]. Freeman and Dmytriyev [27] suggested that CSR activities by a company should be based on the corporate vision and mission statement, and the goal of CSR activities should be creating the most value for corporate stakeholders while ensuring economic sustainability. The stakeholder theory sees that adding more value to one stakeholder will result in overall value to other stakeholders owing to the interdependency among them. The perspective seems to encourage companies to select the recipients of CSR efforts based on the contribution to society [28]. However, when a company weighs claims from multiple stakeholders, the company should decide on the beneficiary of its CSR activities based on power, legitimacy, and urgency [29].

CSR considers some stakeholder value to be more important, and customers and employees are considered key stakeholders of corporations [27,30]. Managing CSR related to employees and customers is both critical and strategic. Employees are an especially vital asset, as well as a key success factor for the company [31], and they embody the main stakeholder group affecting the quality of goods and services [32]. A company's CSR activities are found to boost employees' intrinsic motivations, commitment, trust, improved engagement, workplace culture, and better ethical behavior [33]. Therefore, the implementation of CSR activities leads to positive employees' perception of the workplace, enabling the organization to achieve its desired outcomes and organizational development [34].

Stakeholder perceptions are often used to measure the level of CSR [35]. There are multiple domains that the perception of CSR could cover: customers, employees, environmental groups, suppliers, the local community, society, and shareholders. Perceptions of customer CSR will influence the reputation of a firm and loyalty to the firm $[7,8]$. While perception can be significantly different from the actual CSR activities of the firm, CSR perception in employees can be valuable in studies on behavioral outcomes from employees [30]. Previous research into employee CSR perception found that when employees perceive corporate CSR activities positively, they engage in work better [36], show higher productivity [37], have increased OC [38], and stay in their jobs longer [39]. In addition, CSR-conscious companies will have a larger potential employee pool and a greater chance of recruiting better employees [17]. Sarfraz et al. [39] suggested that employees' positive perceptions of the firm's CSR initiatives will convince those employees that the firm will practice a positive level of employee CSR as well.

Previous studies used perceptions of CSR to predict customers' and employees' attitudes and behavioral outcomes [30,31,40]. For our study, we adopted and modified the definition of CSR by Davis and Blomstrom [26] in order to define employee perception of customer-related CSR and employee-related CSR. We define employee perception of customer-related CSR as "employees' perception of the managerial obligation to take action to protect and improve the customers' welfare as well as the interest of the company." In addition, we define employees' perception of employee-related CSR as "employees' perception of the managerial obligation to take action to protect and improve the employees' welfare as well as the interest of the company."

\subsection{The Relationship between CSR Perception and Intrinsic Motivation}

According to Rego et al. [41] the employees' perception of corporate citizenship will improve employee commitment. Similarly, hotel employees' organizational identification is influenced positively by their perception of CSR activities [17]. Higher Common Good Balance Sheet scores for firms are related positively to employee job-related attitudes and behaviors, including identification with the company, increased organizational support, more meaningfulness in their work, and improved organizational citizenship behavior. 
Other studies confirmed that the perception of corporate CSR activities by employees enhances employees' OC [31,41,42].

When a specific type of motivation is required, well-designed rewards can induce it [43]. An employee's performance of tasks is based on both extrinsic and intrinsic motivation. Extrinsic motivation is referred to as "the performance of an activity in order to attain some separable outcome" [44], and extrinsic motivators include competitive salary, fringe benefits, and bonuses. Intrinsic motivation is defined as "doing an activity for the inherent satisfaction of the activity itself" and includes enjoyment of the job, the joy of working with coworkers, satisfaction derived from the job, challenges in performing tasks, feeling proud of the company, and other positive, non-monetary rewards [44]. Intrinsic motivation refers to self-driven, voluntary performance of tasks due to enjoyment or joy from the activity itself. While work implies extrinsic rewards, employees' perception of CSR activities is more related to intrinsic motivation [4]. These CSR activities, which originate not from profitability but an investment in morality, are more than sources of expense.

An organization participating in CSR activities is likely to create a positive work environment where employees are intrinsically motivated to work well. According to Deci et al. [43], a meta-analysis of 128 studies showed that positive feedback and self-reported interest influenced intrinsic motivation positively. When an employee finds meaningfulness in work through the company's CSR activities, their intrinsic motivation tends to increase while boosting innovation [45]. Intrinsic motivation mediates the relationship between employees' perception of CSR and creativity [46]. Socially responsible firms influence the intrinsic motivation from employees' willingness to make positive changes to their work environment [47]. In research on a Malaysian banking firm, Jie and Hasan [48] found a moderate and positive relationship between determinants of CSR and intrinsic job motivation. Hence, the following hypotheses were formulated:

Hypothesis 1 (H1a). Employees' perception of customer-related CSR relates positively to employee intrinsic motivation.

Hypothesis 1 (H1b). Employees' perception of employee-related CSR relates positively to employee intrinsic motivation.

\subsection{The Relationship between Intrinsic Motivation and $O C$}

OC and motivation are good predictors of satisfaction and quality of work life [49]. Among the factors concerning organizational performance discussed in previous studies is OC [31]. OC is related to a strong desire to remain a member of an organization, strong confidence in taking on the values and goals of the organization, and a willingness to make considerable efforts for the organization [31]. Thus, employees with great OC tend to put extra efforts into improving the performance of the organization [23].

Because OC is related to organizational outcome, companies need to find ways to strengthen it. Canrinus et al. [50] argued that motivation is one of the important factors determining OC. As motivation affects and determines one's behavior, employees need to sustain their motivation [51]. Chalofsky and Krishna [52] described a deeper level of intrinsic motivation exhibited as the interplay among meaningful work, employee commitment, and employee engagement. Through the processes of identification, congruence, and internalization of the organizational goals and values, employees become committed to the organization; in turn, the organization provides organizational support, creating an environment for the continual fostering of emergent employees, who are intrinsically motivated and engaged with the organization in a most efficient way. Intrinsic motivation is found to have a significant relationship with OC [53]. Therefore:

Hypothesis 2 (H2). Employee intrinsic motivation relates positively to OC. 


\subsection{The Effect of Intrinsic Motivation Mediating the Association between Employees' CSR Perception and $O C$}

According to one previous study on the relationship between employees' perception of CSR changes (general, environment-related, and money-related) and employee commitment, there is a direct and significant effect on commitment from the relationship between the perception of general CSR change and the perception of environment-related CSR change [54]. In fact, employees working for the same company can form a perception of corporate CSR performance in different ways [55]. Employees perceive CSR activities differently due to (1) the degree to which they value the CSR activities and/or (2) the degree to which they are likely to be affected by the CSR activities [56]. If an organization provides CSR activities that employees perceive as valuable, it is likely to increase positive attitudes, including employees' commitment to the organization. In other words, when employees receive benefits from organizations, they tend to feel obligated to show commitment as repayment for the benefits [23]. Thus, how employees perceive CSR can affect their work behaviors, attitudes, and/or commitment [20].

The relationship between CSR perception and OC has been proven in previous studies, as described in the previous paragraph. In the relationship between the two elements, intrinsic motivation can play a mediating role. It is reasonable to expect employees' responses to the company's CSR, and their contributions to the organization, may vary depending on the motivational factors in the employees [23]. Motivation is closely related to the sensory formation process by directly controlling each member's perception and behavior [22]. Perception influences employee behavioral outcomes via intrinsic motivation [46]; therefore, employees' positive CSR perception should strengthen their CSR-induced performance through intrinsic motivation. Intrinsic motivation is a key determinant of employees' behavioral outcomes, and intrinsically motivated employees develop new skills and engage deeply in their work [57]. Within a service such as the hotel industry, the quality of service has a close relationship with OC. Intrinsic motivators, such as positive feedback to employees, empowerment through delegation, and opportunities to learn, influence employees to provide better services to customers through OC [58]. Therefore, the relationship between OC and employees' perceived CSR to customers and to themselves can be affected by the employee's intrinsic motivation. Thus:

Hypothesis 3 (H3a). Intrinsic motivation mediates the relationship between employees' perception of customer-related CSR and OC.

Hypothesis $3 \mathbf{( H 3 b ) . ~ I n t r i n s i c ~ m o t i v a t i o n ~ m e d i a t e s ~ t h e ~ r e l a t i o n s h i p ~ b e t w e e n ~ e m p l o y e e s ' ~ p e r c e p t i o n ~}$ of employee-related CSR and OC.

\subsection{The Moderating Effect of Employees' Job Levels in the CSR-Intrinsic Motivation Link}

Previous studies have suggested that job level directly influences work-related attitudes, such as satisfaction, absenteeism, organizational commitment, participation, and more [59]. One of the reasons for this is that employees at different job levels will have different job experiences [60]. For example, managerial employees may face more uncertainty at work and may accept more responsibilities [61], and therefore, the degree of the responsibilities and the work-related attitudes between managerial and non-managerial employees differ. Job level can influence job satisfaction [24], which is closely related to intrinsic motivation [62]; thus, the level of intrinsic motivation could differ depending on the job level.

In a corporate setting, managers and non-managers take on expected and assumed behaviors and beliefs appropriate to their positions within the organization [24]. The employees' needs also reflect different responsibilities and assumed behavior coming with their job levels, and CSR preference was found to be different based on the job level [63]. Researchers found that managers prefer CSR, compared to non-managers, even though there is no opportunity for personal growth. According to role theory, people 
show patterned behaviors, take on identities, and perform expected behaviors due to their prescribed social roles [64]. Miles et al. [24] show that supervisors exhibit more positive patterns of communications within their job settings compared to hourly employees. Those patterns allow openness and criticism within the work and predicted job satisfaction only among hourly employees. This shows the following: (1) a higher job level comes with a working condition (certain communication patterns included) which is related with job satisfaction, (2) a lower job level personnel can have a higher degree of job satisfaction given the same working conditions as the higher job levels', and, therefore, (3) job level provides different starting grounds in forming job attitude as well as job perception. Job levels should influence how managers and non-non managers perceive their CSR practices and how they form their motivation regarding the job. Thus, these hypotheses are proposed:

Hypothesis 4 (H4a). The job level of the employee will moderate the relationship between the employee's perception of customer-related CSR and the employee's intrinsic motivation such that the relationship between the employee's perception of customer-related CSR and the employee's intrinsic motivation is stronger for managerial-level employees than non-managerial employees.

Hypothesis $4 \mathbf{( H 4 b )}$. The job level of the employee will moderate the relationship between the employee's perception of employee-related CSR and the employee's intrinsic motivation such that the relationship between the employee's perception of employee-related CSR and the employee's intrinsic motivation is stronger for managerial-level employees than non-managerial employees.

Our research model is described in Figure 1.

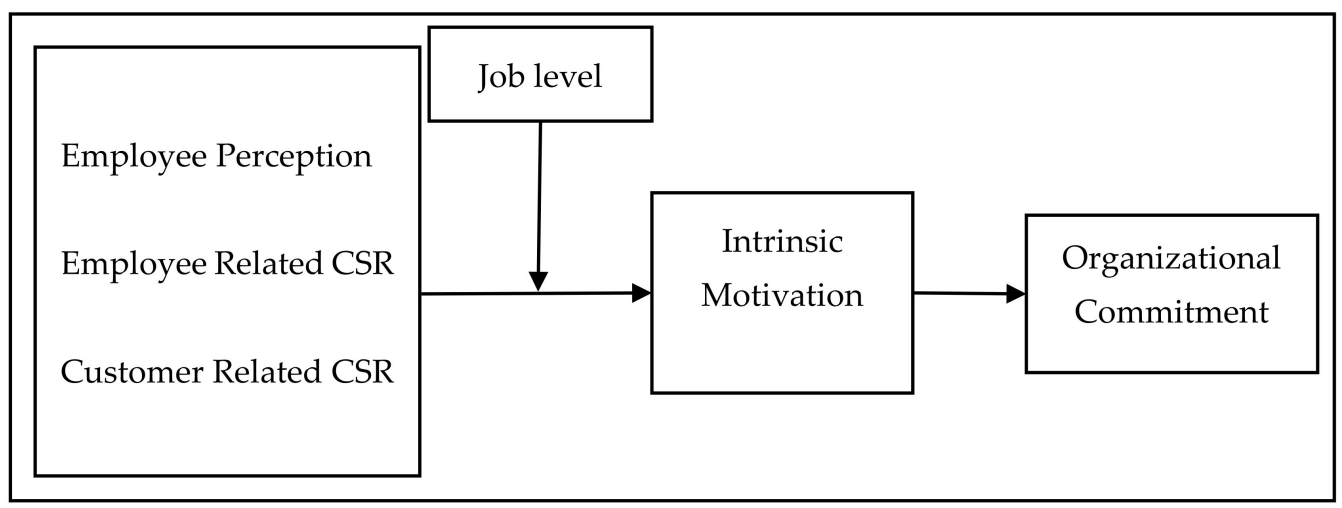

Figure 1. Proposed research model.

\section{Methodology}

\subsection{Data and the Sample}

This study was designed to determine the mediation effect from intrinsic motivation on employees' perception of customer- and employee-related CSR and organizational commitment. We also looked at how job level moderates the relationship between employees' CSR perception and their intrinsic motivation. A total of 310 hotel employees in South Korea participated in a survey-based study. The survey was conducted from 28 July 2021 to 5 September 2021. An online link was sent to participants who had worked in a hotel for more than one year. Of them, 184 participants (59.4\%) worked in local brand hotels while $126(40.6 \%)$ worked for international brand hotels; 146 participants $(47.1 \%)$ worked in hotels that had fewer than 100 employees, and 164 (52.9\%) worked in hotels that had more than 100 employees. In basic demographics, 138 participants $(44.5 \%)$ were male and $172(55.5 \%)$ were female, $168(54.2 \%)$ were between 20 and 29 years old, $54(17.4 \%)$ were between 30 and 39 years old, with 70 participants (22.6\%) between ages 40 and 49 and 18 $(5.8 \%)$ between ages 50 and 59 . Moreover, 70 participants (22.6\%) had worked fewer than 3 years in the hotel, while 240 participants $(77.4 \%)$ had worked more than 3 years in the 
hotel; $184(59.4 \%)$ replied that they worked in non-managerial positions, while $126(40.6 \%)$ held managerial positions.

\subsection{Measures}

Ratings of employee CSR perception, intrinsic motivation, and OC were based on a five-point Likert scale ( $1=$ not at all likely, $5=$ very likely). The section for employeeperceived customer-related CSR listed three items, and the employee-related CSR section listed six items (adapted from Supanti and Butcher [65]). The intrinsic motivation section had three items and was adapted from Kunz [66], while the OC section measured eight items adapted from Youn et al. [67]. The number of employees working at the hotel and the number of years in the business were used as covariates. The number of employees indicated the size of the organizations [68,69], and the firm size influenced the relationship between CSR and performance [70]. Thus, we think CSR perception and OC can be affected by firm size. We included the business period as a control variable because business years influence an organization's CSR-related behavior [71].

To assess the reliability and validity of the variables on the measurements, we used Cronbach's $\alpha$ to test for internal consistency, and we conducted confirmatory factor analysis to demonstrate convergent validity. As shown in Table 1, all measures were found reliable because Cronbach's $\alpha$ exceeded 0.6. In addition, as shown in Table 2, the factor loading of customer-related CSR, employee-related CSR, intrinsic motivation, and OC were all higher than 0.5 .

Table 1. Variables and item description.

\begin{tabular}{|c|c|c|c|c|}
\hline Variables & Items & Mean (SD) & Factor Loading & References \\
\hline \multirow{6}{*}{ Employee-related CSR } & $\begin{array}{l}\text { My company encourages employees to } \\
\text { participate in volunteering activities. }\end{array}$ & $3.21(1.15)$ & 0.75 & $\begin{array}{l}\text { Supanti and } \\
\text { Butcher (2019) }\end{array}$ \\
\hline & $\begin{array}{l}\text { My company's policies encourage } \\
\text { employees to develop their skills and } \\
\text { careers. }\end{array}$ & & 0.90 & \\
\hline & $\begin{array}{l}\text { The management of my company is } \\
\text { concerned with employees' needs and } \\
\text { wants. }\end{array}$ & & 0.82 & \\
\hline & $\begin{array}{l}\text { My company implements flexible policies } \\
\text { to provide a good work and life balance } \\
\text { for employees. }\end{array}$ & & 0.90 & \\
\hline & $\begin{array}{l}\text { The managerial decisions related to } \\
\text { employees are usually fair. }\end{array}$ & & 0.90 & \\
\hline & $\begin{array}{l}\text { My company supports employees who } \\
\text { want to acquire additional education. }\end{array}$ & & 0.86 & \\
\hline \multirow{3}{*}{ Customer-related CSR } & $\begin{array}{l}\text { My company protects consumer rights } \\
\text { beyond the legal requirements. } \\
\text { My company provides full and accurate }\end{array}$ & $4.06(0.88)$ & 0.88 & $\begin{array}{l}\text { Supanti and } \\
\text { Butcher (2019) }\end{array}$ \\
\hline & $\begin{array}{l}\text { information about its products to } \\
\text { customers. }\end{array}$ & & 0.90 & \\
\hline & $\begin{array}{l}\text { Customer satisfaction is highly important } \\
\text { to my company. }\end{array}$ & & 0.89 & \\
\hline \multirow{3}{*}{ Intrinsic motivation } & $\begin{array}{l}\text { I would be willing to work diligently in } \\
\text { this situation because I enjoy this work } \\
\text { very much. }\end{array}$ & $3.80(1.07)$ & 0.96 & Kunz (2020) \\
\hline & $\begin{array}{l}\text { I would be willing to work diligently in } \\
\text { this situation because I have fun doing my } \\
\text { job. }\end{array}$ & & 0.96 & \\
\hline & $\begin{array}{l}\text { I would be willing to work diligently in } \\
\text { this situation for the moments of pleasure } \\
\text { that this job brings me. }\end{array}$ & & 0.92 & \\
\hline
\end{tabular}


Table 1. Cont.

\begin{tabular}{|c|c|c|c|c|}
\hline Variables & Items & Mean (SD) & Factor Loading & References \\
\hline \multirow{8}{*}{$\begin{array}{l}\text { Organizational } \\
\text { Commitment }\end{array}$} & $\begin{array}{l}\text { I talk up my company to friends as a great } \\
\text { company to work. }\end{array}$ & $3.25(0.94)$ & 0.73 & Youn et al. (2018) \\
\hline & $\begin{array}{l}\text { I would accept almost any type of job } \\
\text { assignment in order to keep working for } \\
\text { my company. }\end{array}$ & & 0.79 & \\
\hline & $\begin{array}{l}\text { I find that my values and the company's } \\
\text { values are very similar. }\end{array}$ & & 0.88 & \\
\hline & $\begin{array}{l}\text { I am proud to tell others that I am part of } \\
\text { my company. }\end{array}$ & & 0.87 & \\
\hline & $\begin{array}{l}\text { My company really inspires the very best } \\
\text { in me in the way of job performance. }\end{array}$ & & 0.83 & \\
\hline & $\begin{array}{l}\text { I am extremely glad that I chose to work } \\
\text { for my company over others I was } \\
\text { considering at the time I joined. }\end{array}$ & & 0.89 & \\
\hline & I really care about the fate of my company. & & 0.59 & \\
\hline & $\begin{array}{l}\text { For me, this is the best of all possible } \\
\text { companies for which to work. }\end{array}$ & & 0.87 & \\
\hline
\end{tabular}

Table 2. Correlation and reliability analysis.

\begin{tabular}{|c|c|c|c|c|c|}
\hline & $\begin{array}{c}\text { Customer-Related } \\
\text { CSR }\end{array}$ & $\begin{array}{c}\text { Employee-Related } \\
\text { CSR }\end{array}$ & $\begin{array}{c}\text { Intrinsic } \\
\text { Motivation }\end{array}$ & $\begin{array}{c}\text { Organizational } \\
\text { Commitment }\end{array}$ & Cronbach's $\alpha$ \\
\hline Customer-related CSR & 1 & & & & 0.87 \\
\hline Employee-related CSR & $0.56^{* *}$ & 1 & & & 0.93 \\
\hline Intrinsic motivation & $0.54^{* *}$ & $0.40 * *$ & 1 & & 0.94 \\
\hline $\begin{array}{l}\text { Organizational } \\
\text { Commitment }\end{array}$ & 0.50 ** & $0.57^{* *}$ & $0.62^{* *}$ & 1 & 0.92 \\
\hline
\end{tabular}

Notes: $n=310,{ }^{* *} p<0.01$ (two-tailed test).

\subsection{Results}

We first analyzed whether intrinsic motivation mediates employees' CSR perception and OC. The number of employees working at the hotel and the hotels' operated years were used as covariates. To test proposed hypotheses 1, 2, and 3, model 4 from Hayes' Process macro [72] was used.

As predicted, employees' perception of customer-related CSR related positively to intrinsic motivation ( $b=0.63, \mathrm{SE}=0.06, p<0.01,95 \% \mathrm{CI}[0.51,0.74]$ : H1a supported), and intrinsic motivation related positively to organizational commitment $(b=0.431, \mathrm{SE}=0.05$, $p<0.01,95 \%$ CI [0.32, 0.52]: H2 supported). In addition, the study indicated employees perception of employee-related CSR related positively to intrinsic motivation $(b=0.37$, $\mathrm{SE}=0.05, p<0.01,95 \% \mathrm{CI}[0.27,0.46]:$ H1b supported), and intrinsic motivation related positively to organizational commitment $(b=0.39, \mathrm{SE}=0.05, p<0.01,95 \% \mathrm{CI}[0.32,0.47]$ : H2 supported).

Through mediation analysis, we found that both direct effect from the perception of customer-related CSR on organizational commitment $(b=0.24$, SE $=0.06, p<0.01$, $95 \%$ CI $[0.14,0.35])$ and indirect effects from customer-related CSR on organizational commitment through intrinsic motivation were significant $(b=0.27, \mathrm{SE}=0.04,95 \% \mathrm{CI}$ [0.20, 0.34]: H3a supported), indicating partial mediation (Table 3). Similarly, both direct effect from perception of employee-related CSR on organizational commitment $(b=0.32$, $\mathrm{SE}=0.04, p<0.01,95 \% \mathrm{CI}[0.25,0.39])$ and indirect effects from employee-related CSR on organizational commitment through intrinsic motivation were significant $(b=0.14$, $\mathrm{SE}=0.02,95 \% \mathrm{CI}[0.10,0.20]$ : H3b supported), indicating partial mediation (Table 4). 
Table 3. Mediation result (Customer-related CSR -> Intrinsic Motivation -> Organizational Commitment).

\begin{tabular}{ccccccccc}
\hline & \multicolumn{3}{c}{ Intrinsic Motivation (M) } & \multicolumn{3}{c}{ Organizational Commitment (Y) } \\
\hline & Coeff. & SE & t-Value & $p$-Value & Coeff. & SE & t-Value & $p$-Value \\
\hline Constant & 1.25 & 0.34 & 3.68 & $<0.01$ & 0.64 & 0.29 & 2.32 \\
Customer-related CSR (X) & 0.63 & 0.06 & 10.55 & $<0.01$ & 0.24 & 0.06 & 4.42 & $<0.02$ \\
Number of Employees & 0.23 & 0.10 & 2.22 & 0.03 & 0.05 & 0.08 & 0.63 & 0.53 \\
Company Years & -0.20 & 0.12 & -1.67 & 0.10 & -0.05 & 0.10 & -0.54 & 0.59 \\
Intrinsic Motivation (M) & - & - & - & - & 0.43 & 0.05 & 9.48 & $<0.01$ \\
Model Summary & $\mathrm{R}^{2}=0.43$ & $\mathrm{~F}=57.29$ & $p<0.01$ & & $\mathrm{R}^{2}=0.26$ & $\mathrm{~F}=36.01$ & $p<0.01$ & \\
\hline
\end{tabular}

Table 4. Mediation result (Employee-related CSR -> Intrinsic Motivation -> Organizational Commitment).

\begin{tabular}{ccccccccc}
\hline & \multicolumn{3}{c}{ Intrinsic Motivation (M) } & \multicolumn{3}{c}{ Organizational Commitment (Y) } \\
\hline & Coeff. & SE & t-Value & $p$-Value & Coeff. & SE & t-Value & $p$-Value \\
\hline Constant & 2.38 & 0.32 & 7.45 & $<0.01$ & 0.68 & 0.24 & 2.85 & $<0.01$ \\
Employee-related CSR (X) & 0.37 & 0.05 & 7.73 & $<0.01$ & 0.32 & 0.04 & 8.94 & $<0.01$ \\
Number of Employees & 0.46 & 0.11 & 4.17 & $<0.01$ & 0.15 & 0.08 & 1.95 & 0.05 \\
Company Years & -0.26 & 0.13 & -2.00 & 0.05 & -0.09 & 0.09 & -1.04 & 0.30 \\
Intrinsic Motivation (M) & - & - & - & - & 0.39 & 0.04 & 10.07 & $<0.01$ \\
Model Summary & $\mathrm{R}^{2}=0.52$ & $\mathrm{~F}=82.11$ & $p<0.01$ & & $\mathrm{R}^{2}=0.60$ & $\mathrm{~F}=57.00$ & $p<0.01$ & \\
\hline
\end{tabular}

Next, we examined the moderated mediation model through intrinsic motivation using Hayes' Process macro (model 7) [72]. First, we examined whether job level moderates the intrinsic motivation relationship between employees' perception of customer-related and employee-related CSR. Once again, the number of employees working at the hotel and hotels' operated years were used as covariates. As predicted, job level moderated the relationship between customer-related CSR and intrinsic motivation $(b=0.45, S E=0.12$, $p<0.01,95 \%$ CI $[0.21,0.68]$ : H4a supported). Additionally, job level moderated the relationship between employee-related CSR and intrinsic motivation $(b=0.37, S E=0.10$, $p<0.01,95 \%$ CI $[0.17,0.56]$ : H4b supported).

The post-doc test indicated that when customer-related CSR is low, the level of intrinsic motivation will not differ between managerial and non-managerial employees $($ non-managerial $=3.27$, managerial $=3.12, p=0.40,95 \%$ CI $[-0.44,0.17]$ ). However, when customer-related CSR is high, the level of intrinsic motivation will significantly differ between managerial and non-managerial employees (non-managerial $=4.03$, managerial $=4.67, p<0.01,95 \%$ CI $[0.36,0.91])$. In addition, when employee-related CSR is low, the level of intrinsic motivation will not differ between managerial and non-managerial employees (non-managerial $=3.42$, managerial $=3.24, p=0.71,95 \%$ CI $[-0.39,0.27]$ ). However, when employee-related CSR is high, the level of intrinsic motivation will significantly differ between managerial and non-managerial employees (non-managerial $=4.03$, managerial $=4.67, p<0.01,95 \%$ CI $[0.41,1.02]$ ) (See Figure 2).

Through moderated mediation analysis, we found that both the direct effect of customer-related CSR job level on organizational commitment $(b=0.24, \mathrm{SE}=0.06, p<0.01$, $95 \%$ CI $[0.14,0.35])$ and indirect effect of customer-related CSR job level on organizational commitment through intrinsic motivation are significant (Index: 0.19, $\mathrm{SE}=0.06,95 \% \mathrm{CI}$ $[0.09,0.32])$, indicating partial mediation (Table 5). Similarly, both the direct effect of employee-related CSRjob level on organizational commitment $(\mathrm{b}=0.32, \mathrm{SE}=0.04, p<0.01$, $95 \%$ CI $[0.25,0.39])$ and the indirect effect of customer-related CSR job level on organization commitment through intrinsic motivation are significant (Index: 0.14, SE $=0.05,95 \% \mathrm{CI}$ $[0.05,0.24])$, indicating partial mediation (Table 6). 


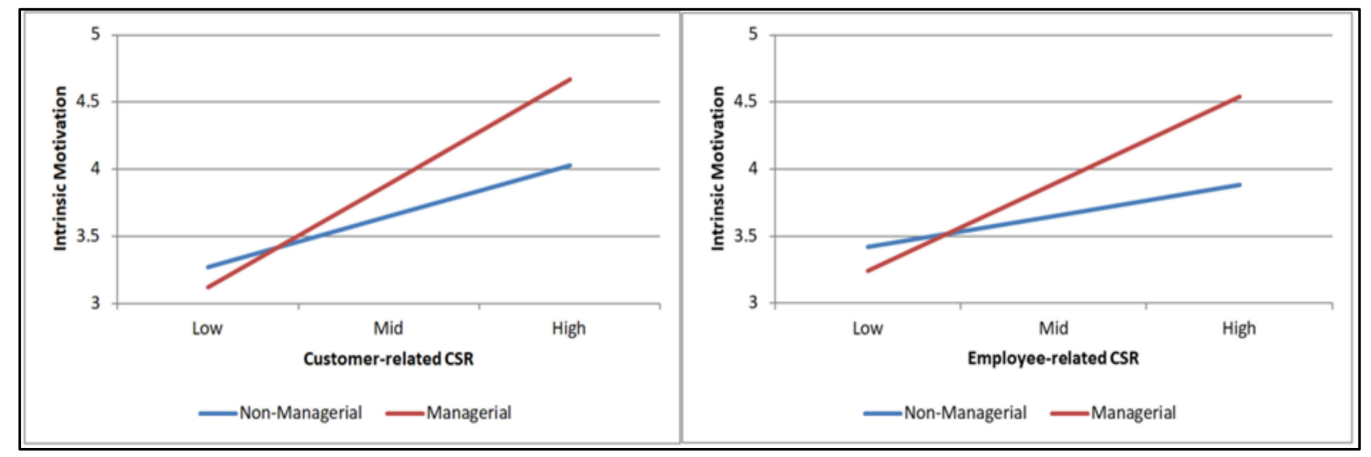

Figure 2. Intrinsic motivation based on employees' perception of customer- and employee-related CSR and job level.

Table 5. Moderated mediation result (Customer-related CSR $\times$ Job Level $->$ Intrinsic Motivation $->$ Organizational Commitment).

\begin{tabular}{|c|c|c|c|c|c|c|c|c|}
\hline & \multicolumn{4}{|c|}{ Intrinsic Motivation (M) } & \multicolumn{4}{|c|}{ Organizational Commitment (Y) } \\
\hline & Coeff. & SE & t-Value & $p$-Value & Coeff. & SE & t-Value & $p$-Value \\
\hline Constant & 4.01 & 0.27 & 14.88 & $<0.01$ & 1.63 & 0.27 & 5.96 & $<0.01$ \\
\hline Customer-related CSR (X) & 0.62 & 0.06 & 10.54 & $<0.01$ & 0.24 & 0.06 & 4.42 & $<0.01$ \\
\hline Job Level $(\mathrm{W})$ & 0.24 & 0.11 & 2.25 & 0.03 & - & - & - & - \\
\hline Customer-related CSR $\times$ Job Level & 0.45 & 0.12 & 3.77 & $<0.01$ & - & - & - & - \\
\hline Number of Employees & 0.15 & 0.11 & 1.40 & 0.16 & 0.05 & 0.08 & 0.63 & 0.53 \\
\hline Company Years & -0.27 & 0.12 & -2.29 & 0.02 & -0.05 & 0.10 & -0.54 & 0.59 \\
\hline Intrinsic Motivation (M) & - & - & - & - & 0.43 & 0.05 & 9.48 & $<0.01$ \\
\hline Model Summary & $\mathrm{R}^{2}=0.35$ & $F=32.93$ & $p<0.01$ & & $\mathrm{R}^{2}=0.43$ & $F=57.29$ & $p<0.01$ & \\
\hline
\end{tabular}

Table 6. Moderated mediation result (Employee-related CSR $\times$ Job Level $->$ Intrinsic Motivation $->$ Organizational Commitment).

\begin{tabular}{ccccccccc}
\hline & \multicolumn{3}{c}{ Intrinsic Motivation (M) } & \multicolumn{3}{c}{ Organizational Commitment (Y) } \\
\hline & Coeff. & SE & t-Value & $p$-Value & Coeff. & SE & t-Value & $p$-Value \\
\hline Constant & 3.79 & 0.29 & 14.88 & $<0.01$ & 1.70 & 0.24 & 7.10 & $<0.01$ \\
Employee-related CSR (X) & 0.35 & 0.05 & 10.54 & $<0.01$ & 0.32 & 0.04 & 8.94 & $<0.01$ \\
Job Level (W) & 0.24 & 0.12 & 2.25 & 0.03 & - & - & - & - \\
Employee-related CSR $\times$ Job Level & 0.37 & 0.10 & 3.77 & $<0.01$ & - & - & - & 1.95 \\
Number of Employees & 0.37 & 0.11 & 1.40 & 0.16 & 0.15 & 0.08 & 0.05 \\
Company Years & -0.27 & 0.13 & -2.29 & 0.02 & -0.09 & 0.09 & -1.04 & 0.30 \\
Intrinsic Motivation (M) & - & - & - & - & 0.39 & 0.04 & 10.07 & $<0.01$ \\
Model Summary & $\mathrm{R}^{2}=0.26$ & $\mathrm{~F}=21.09$ & $p<0.01$ & & $\mathrm{R}^{2}=0.52$ & $\mathrm{~F}=82.11$ & $p<0.01$ & \\
\hline
\end{tabular}

\section{Discussion}

The results of our study show that employees' perception of customer-related CSR and employee-related CSR influences employees' intrinsic motivation positively (H1a and H1b). Similar to our results, Kunz hypothesized that a firm's engagement in CSR activities will foster an optimal environment for intrinsic motivation [66], a place that feels caring and relationship-forming, and found a significant influence from CSR on intrinsic motivation. However, there is research showing conflicting results. For example, Khan et al. [73] found no influence from internal CSR on intrinsic motivation but found a positive and significant influence between external CSR and intrinsic motivation. Our research measured employees' CSR perception, rather than actual CSR practices, so the difference might have resulted in the conflict. Another reason might be that economic and cultural factors (Pakistan vs. South Korea) could produce different results. The relationship between 
corporate CSR and intrinsic motivation has not been researched fully [66], and there is a need to verify the relationship in future research.

Intrinsic motivation was found to influence OC (H2). OC refers to a psychological connection between an employee and an organization, and it influences the willingness of the employee to put in extra effort for the organization's cause, creating a desire to stay in the organization, and identification with the core values and goals of the organization [52]. The results of our research show the direct relationship between intrinsic motivation and OC, which is obvious considering the close conceptual relationship between the two.

Intrinsic motivation as a mediator between the employee perception of CSR and OC was proven by this study (H3a and H3b). Similar research by Hur et al. [46] was based on hotel employees in South Korea, and their results showed that intrinsic motivation and compassion at work fully mediated the relationship. The hotel industry is among the worst industries in terms of employee retention, with rates running double the national average in the U.S. for more than a decade [74]. The strategic management of human resources is critical within a labor-intensive industry, where the value of the service is reliant upon workers' skill sets [63]. Companies practicing CSR are found to attract and keep employees even at lower monetary compensation [75]. Therefore, enhancing the CSR perception can be beneficial in managing human resources in an industry with a high turnover rate.

We tested the moderating influence of job level on the relationship between employees' CSR perceptions and intrinsic motivation ( $\mathrm{H} 4 \mathrm{a}$ and $\mathrm{H} 4 \mathrm{~b})$ and found the interaction to be strong. When CSR perception is high (in both customer-related and employee-related CSR), managers demonstrated significantly higher intrinsic motivation. According to role theory, people show patterned behaviors, assume identities, and perform expected behaviors according to their prescribed social roles based on norms, beliefs, and attitudes [64]. In the corporate setting, managers and non-managers would take on expected and assumed behaviors and beliefs appropriate to their positions within the organization [24]. The results of the study suggest that non-management employees would have a positive work attitude from their jobs when they can enjoy a more positive organizational culture-in this case, a culture promoting CSR activities as an environment to enhance employees' social roles.

This result indicates that it is particularly important for managerial-level employees to understand CSR activities in the organization. Compared to non-managerial-level employees, these employees are more motivated and committed to their organizations when they positively perceive CSR activities in their organizations. Hotel managers should design their CSR training programs and information sessions focusing on these managerial position employees. For non-managerial employees, empowering them is crucial. Hotels can make them feel empowered by restructuring their organizations. The delegation of power to lower-level employees will also encourage them to feel more in control, which can induce higher level of motivation and organizational commitment when they perceive CSR activities of the organization. These employees can enhance customer satisfaction by delivering quality service and building strong relationship with their customers. Eventually, the result demonstrates that it is necessary for hotels to apply differently depending on employees' job level as a way to bring positive results for CSR activities, and CSR activities become preconditions to provoke a positive response among stakeholders [76]. All the hypotheses were supported, and employees' perception of customer-related CSR and employee-related CSR both had significant influences on intrinsic motivation as well as OC. The indifferent results between customer-related CSR and employee-related CSR could be due to both perceptions being those of the employees. Therefore, irrespective of the stakeholder benefits from the CSR activities, we believe CSR perception represents the cultural atmosphere of the hotels the employees are working in. How employees perceive the environment is highly related to their innate enjoyment of tasks at work as well as their commitment to their work.

This study tested the mediation effects of intrinsic motivation on hotel employees' perception of customer-related and employee-related CSR and organizational commitment. In addition, as a moderator, job level was selected and tested in the relationship between 
employees' CSR perception and their intrinsic motivation. All hypotheses were supported, showing the roles of intrinsic motivator and job level as mediator and moderator, respectively. An intrinsic motivator is typically not tied to tasks in a job-related setting, since intrinsic motivation requires internalization of the tasks and an environment providing joy and pleasure [44]. However, a workplace perceived as one with a CSR culture seems to meet the requirements for intrinsic motivation to thrive. Commitment that is closely related to intrinsic motivation should make an employee want to stay with the company because of job satisfaction, sharing organizational goals, and valuing the organization's success.

While there are many stakeholders of a corporation, this research focuses on employees as the stakeholder of interest. The service industry, especially the hospitality industry, is reliant upon employees as the main producer and deliverer of services. Within the hotel and casino industry, CSR is found to influence both the short-term profit and the long-term profitability of companies [77]. Therefore, the quality of human resources, as well as the instilled ethical values and processes within the organization, would be essential in maintaining competitive advantages within the industry.

\section{Contributions and Limitations}

This paper contributes to the existing CSR literature by confirming a mediating process and identifying a moderating process in the links among CSR perception, intrinsic motivation, and OC. The findings indicate the critical role of intrinsic motivation in the association between CSR perception and OC. Although some research identified a relationship between CSR activities and employee motivation, the mediating role of intrinsic motivation is still worth investigating in relation to OC. Moreover, the job level will function as a critical moderating factor to explain the link between CSR perception and intrinsic motivation. Job level has been investigated in relation to employee job satisfaction [59]; however, no study could be found that tested the moderating effect of job level in the context of CSR and intrinsic motivation. In addition, the results of this study enhance the understanding of CSR based on the stakeholder theory.

Regarding practical implications, hotels need to recognize that employees (a key stakeholder group) can form OC through their intrinsic motivation. Previous studies indicate that enhancing employees' intrinsic motivation can make employees willingly create a good working environment [47]. Our study shows that enhanced intrinsic motivation enables a higher level of OC, which will eventually reduce the turnover rate of employees [51]. From the perspective of employees as well as their employers, intrinsic motivation can enhance positive service performance and result in a positive human management practice, respectively [78].

Additionally, management in the hotel industry needs to enhance CSR perception among employees, because it brings better motivated and engaged employees. Firms can inform and educate their employees about CSR activities for building better perception of the firm's CRS practices, and hotel owners and CSR managers need to design their internal corporate communication for better CSR recognition. The role of CSR perception can benefit beyond employees and the employers. Customers will receive quality service and more accurate information by interacting with motivated and committed employees [78]. Hence, organizations that can retain employees who are knowledgeable and motivated can have a competitive advantage in human resources within the hospitality industry [79]. Furthermore, non-imitable competitive advantages can lead to an organization's profitability [80].

This study contributes to current knowledge of CSR, and provides practical implications to hoteliers, but there are several limitations. First, this study was conducted with South Korean hotel employees. For generalizability, future studies can be designed for other industries across different nations. Second, OC can be divided into different types of commitment (normative, continuance, and affective [81]), but this study employed overall OC singularly. Further studies are required to test whether CSR perception has the same effect on different types of OC. Third, we used only intrinsic motivation as a mediator. Extrinsic motivation, or both intrinsic and extrinsic motivation, might mediate the relation- 
ship between CSR perception and OC even better. According to a study by Deci et al. [43], positive feedback and self-reported interest influenced intrinsic motivation positively; however, intrinsic motivation was lowered significantly when various types of extrinsic rewards were given. Therefore, further research is required to identify the role of extrinsic motivation and to differentiate between intrinsic motivation and extrinsic motivation as mediators. Finally, we used perception of employees to measure customer-related as well as employee-related CSR. The perceptions of employees could be biased due to their roles as employee or their sense of belongingness to the company. Introducing the customer perception for customer-related CSR, or using more accurate measures of employee CSR and customer CSR, could bring a more relevant picture of the role that CSR plays on OC.

Author Contributions: Methodology was written by J.R.H., whereas the residual work was completed by K.-S.O. and S.R.P. All authors have read and agreed to the published version of the manuscript.

Funding: This research received no external funding.

Institutional Review Board Statement: Not applicable.

Informed Consent Statement: Not applicable.

Data Availability Statement: Not applicable.

Conflicts of Interest: The authors declare no conflict of interest. All questionnaire items in Table 1 were adapted by the authors, and we confirm that we did not directly copy any sources.

\section{References}

1. Malik, M. Value-Enhancing Capabilities of CSR: A Brief Review of Contemporary Literature. J. Bus. Ethics 2015, 127, 419-438. [CrossRef]

2. Park, S.R.; Jang, J.Y. The Impact of ESG Management on Investment Decision: Institutional Investors' Perceptions of CountrySpecific ESG Criteria. Int. J. Financ. Stud. 2021, 9, 48. [CrossRef]

3. Xu, J.; Liu, F.; Shang, Y. R\&D investment, ESG performance and green innovation performance: Evidence from China. Kybernetes 2021, 50, 737-756. [CrossRef]

4. Grimstad, S.M.F.; Glavee-Geo, R.; Fjørtoft, B.E. SMEs motivations for CSR: An exploratory study. Eur. Bus. Rev. 2020, 32, 553-572. [CrossRef]

5. Osagie, E.R.; Wesselink, R.; Blok, V.; Lans, T.E.; Mulder, M. Individual Competencies for Corporate Social Responsibility: A Literature and Practice Perspective. J. Bus. Ethics 2016, 135, 233-252. [CrossRef]

6. Shin, W.-Y.; Hong, S.-W. The Effect of CSR Activities of Jeju Lodging Companies on Management Performance. J. Tour. Leis. Res. 2021, 33, 249-266. [CrossRef]

7. Ajina, A.S.; Japutra, A.; Nguyen, B.; Alwi, S.F.S.; Al-Hajla, A.H. The importance of CSR initiatives in building customer support and loyalty. Asia Pac. J. Mark. Logist. 2019, 31, 691-713. [CrossRef]

8. Osakwe, C.N.; Yusuf, T.O. CSR: A roadmap towards customer loyalty. Total. Qual. Manag. Bus. Excel. 2020, 32, 1424-1440. [CrossRef]

9. Hategan, C.-D.; Sirghi, N.; Curea-Pitorac, R.-I.; Hategan, V.-P. Doing Well or Doing Good: The Relationship between Corporate Social Responsibility and Profit in Romanian Companies. Sustainability 2018, 10, 1041. [CrossRef]

10. Porter, M.; Serafeim, G.; Kramer, M. Where ESG fails. Institutional Investor, 16 October 2019; pp. 1-17.

11. Sinthupundaja, J.; Chiadamrong, N.; Kohda, Y. Internal capabilities, external cooperation and proactive CSR on financial performance. Serv. Ind. J. 2019, 39, 1099-1122. [CrossRef]

12. Srivastava, S.; Singh, N. Do Corporate Social Responsibility (CSR) initiatives boost customer retention in the hotel industry? A moderation-mediation approach. J. Hosp. Mark. Manag. 2021, 30, 459-485. [CrossRef]

13. Kim, H.; Rhou, Y.; Topcuoglu, E.; Kim, Y.G. Why hotel employees care about Corporate Social Responsibility (CSR): Using need satisfaction theory. Int. J. Hosp. Manag. 2020, 87, 102505. [CrossRef]

14. Wang, C.; Hu, R.; Zhang, T. Corporate social responsibility in international hotel chains and its effects on local employees: Scale development and empirical testing in China. Int. J. Hosp. Manag. 2020, 90, 102598. [CrossRef]

15. Jani, D.; Han, H. Personality, satisfaction, image, ambience, and loyalty: Testing their relationships in the hotel industry. Int. J. Hosp. Manag. 2014, 37, 11-20. [CrossRef]

16. Tepeci, M. Increasing brand loyalty in the hospitality industry. Int. J. Contemp. Hosp. Manag. 1999, 11, 223-230. [CrossRef]

17. Park, S.-Y.; Levy, S.E. Corporate social responsibility: Perspectives of hotel frontline employees. Int. J. Contemp. Hosp. Manag. 2014, 26, 332-348. [CrossRef]

18. Bohdanowicz, P.; Zientara, P.; Novotna, E. International hotel chains and environmental protection: An analysis of Hilton's we care!programme (Europe, 2006-2008). J. Sustain. Tour. 2011, 19, 797-816. [CrossRef] 
19. Serra-Cantallops, A.; Peña-Miranda, D.D.; Ramón-Cardona, J.; Martorell-Cunill, O. Progress in Research on CSR and the Hotel Industry (2006-2015). Cornell Hosp. Q. 2017, 59, 15-38. [CrossRef]

20. Glavas, A. Corporate social responsibility and organizational psychology: An integrative review. Front. Psychol. 2016, 7, 144. [CrossRef]

21. Bouraoui, K.; Bensemmane, S.; Ohana, M.; Russo, M. Corporate social responsibility and employees' affective commitment. Manag. Decis. 2019, 57, 152-167. [CrossRef]

22. Grant, A.M. Does intrinsic motivation fuel the prosocial fire? Motivational synergy in predicting persistence, performance, and productivity. J. Appl. Psychol. 2008, 93, 48-58. [CrossRef]

23. Kim, M.-J.; Kim, B.-J. The Performance Implication of Corporate Social Responsibility: The Moderating Role of Employee's Prosocial Motivation. Int. J. Environ. Res. Public Health 2021, 18, 3128. [CrossRef]

24. Miles, E.W.; Patrick, S.L.; King Jr, W.C. Job level as a systemic variable in predicting the relationship between supervisory communication and job satisfaction. J. Occup. Organ. Psychol. 1996, 69, 277-292. [CrossRef]

25. Freeman, R.E. Strategic Management: A Stakeholder Approach; Cambridge University Press: New York, NY, USA, 2010.

26. Davis, K.; Blomstrom, R.I. Business and Society: Environment and Responsibility Management; McGraw-Hill: New York, NY, USA, 1975.

27. Freeman, E.; Dmytriyev, S. Corporate social responsibility and stakeholder theory: Learning from each other. Emerg. Issues Manag. 2017, 1, 7-15. [CrossRef]

28. Donaldson, T.; Preston, L.E. The stakeholder theory of the corporation: Concepts, evidence, and implications. Acad. Manag. Rev. 1995, 20, 65-91. [CrossRef]

29. Mitchell, R.K.; Agle, B.R.; Wood, D.J. Toward a theory of stakeholder identification and salience: Defining the principle of who and what really counts. Acad. Manag. Rev. 1997, 22, 853-886. [CrossRef]

30. Oberseder, M.; Schelegelmich, B.B. Consumers' perceptions of corporate social responsibility: Scale development and validation. J. Bus. Ethics 2013, 124, 101-115. [CrossRef]

31. George, N.A.; Aboobaker, N.; Edward, M. Corporate social responsibility, organizational trust and commitment: A moderated mediation model. Pers. Rev. 2021, 50, 1093-1111. [CrossRef]

32. Lee, Y.-K.; Kim, Y.S.; Lee, K.H.; Li, D.-X. The impact of CSR on relationship quality and relationship outcomes: A perspective of service employees. Int. J. Hosp. Manag. 2012, 31, 745-756. [CrossRef]

33. Backhaus, K.B.; Stone, B.A.; Heiner, K. Exploring the relationship between corporate social performance and employer attractiveness. Bus. Soc. 2002, 41, 292-318. [CrossRef]

34. Stankevičiūtė, Ž.; Wereda, W. Universalism values and organisational citizenship behaviour referring to employee perception of corporate social responsibility. Manag. Mark. Chall. Knowl. Soc. 2020, 15, 302-325. [CrossRef]

35. Costa, R.; Menichini, T. A multidimensional approach for CSR assessment: The importance of the stakeholder perception. Expert Syst. Appl. 2013, 40,150-161. [CrossRef]

36. Agarwal, U.A.; Datta, S.; Blake-Beard, S.; Bhargava, S. Linking LMX, innovative work behaviour and turnover intentions: The mediating role of work engagement. Career Dev. Int. 2012, 17, 208-230. [CrossRef]

37. Park, K.O. How CSV and CSR Affect Organizational Performance: A Productive Behavior Perspective. Int. J. Environ. Res. Public Health 2020, 17, 2556. [CrossRef]

38. Lee, S.; Lee, K.; Gao, Y.; Xiao, Q.; Conklin, M. Do a company's sincere intentions with CSR initiative matter to employees? A comparison of customer-related and employee-related initiatives. J. Glob. Responsib. 2018, 9, 355-371. [CrossRef]

39. Sarfraz, M.; Qun, W.; Abdullah, M.I.; Alvi, A.T. Employees' Perception of Corporate Social Responsibility Impact on Employee Outcomes: Mediating Role of Organizational Justice for Small and Medium Enterprises (SMEs). Sustainability 2018, $10,2429$. [CrossRef]

40. Turker, D. Measuring Corporate Social Responsibility: A Scale Development Study. J. Bus. Ethics 2008, 85, 411-427. [CrossRef]

41. Rego, A.; Leal, S.; Cunha, M.P.E.; Faria, J.; Pinho, C. How the Perceptions of Five Dimensions of Corporate Citizenship and Their Inter-Inconsistencies Predict Affective Commitment. J. Bus. Ethics 2009, 94, 107-127. [CrossRef]

42. Hofman, P.; Newman, A. The impact of perceived corporate social responsibility on organizational commitment and the moderating role of collectivism and masculinity: Evidence from China. Int. J. Hum. Resour. Manag. 2013, 25, 631-652. [CrossRef]

43. Deci, E.; Koestner, R.; Ryan, R.M. A meta-analytic review of experiments examining the effects of extrinsic rewards on intrinsic motivation. Psychol. Bull. 1999, 125, 627-668. [CrossRef] [PubMed]

44. Ryan, R.M.; Deci, E.L. Self-determination theory and the facilitation of intrinsic motivation, social development, and well-being. Am. Psychol. 2000, 55, 68-78. [CrossRef] [PubMed]

45. Kim, B.-J.; Chang, Y.K.; Kim, T.-H. How Does Corporate Social Responsibility Promote Innovation? The Sequential Mediating Mechanism of Employees' Meaningfulness of Work and Intrinsic Motivation. In Proceedings of the 51th Hawaii International Conference on System Sciences, Waikoloa Village, HI, USA, 3-6 January 2018.

46. Hur, W.-M.; Moon, T.-W.; Ko, S.-H. How Employees' Perceptions of CSR Increase Employee Creativity: Mediating Mechanisms of Compassion at Work and Intrinsic Motivation. J. Bus. Ethics 2018, 153, 629-644. [CrossRef]

47. Melynyte, O.; Ruzevicius, J. The study of interconnections of corporate social responsibility and human resource management. Econ. Manag. 2008, 13, 817-823. 
48. Jie, C.T.; Hasan, N.A. Determinants of Corporate Social Responsibility (CSR) and intrinsic job motivation: A case of Malaysian banking company. Malays. J. Soc. Sci. Humanit. 2016, 1, 25-35.

49. Dorta-Afonso, D.; González-De-La-Rosa, M.; García-Rodríguez, F.J.; Romero-Domínguez, L. Effects of High-Performance Work Systems (HPWS) on Hospitality Employees' Outcomes through Their Organizational Commitment, Motivation, and Job Satisfaction. Sustainability 2021, 13, 3226. [CrossRef]

50. Canrinus, E.T.; Helms-Lorenz, M.; Beijaard, D.; Buitink, J.; Hofman, A. Profiling teachers' sense of professional identity. Educ. Stud. 2011, 37, 593-608. [CrossRef]

51. Imran, R.; Allil, K.; Mahmoud, A.B. Teacher's turnover intentions: Examining the impact of motivation and organizational commitment. Int. J. Educ. Manag. 2017, 31, 828-842. [CrossRef]

52. Chalofsky, N.; Krishna, V. Meaningfulness, Commitment, and Engagement:The Intersection of a Deeper Level of Intrinsic Motivation. Adv. Dev. Hum. Resour. 2009, 11, 189-203. [CrossRef]

53. Choong, Y.-O.; Wong, K.-L.; Lau, T.-C. Psychological empowerment and organizational commitment in the Malaysian private higher education institutions. Int. J. Acad. Res. 2011, 1, 236-245.

54. Zhou, Y.; Poon, P.; Huang, G. Corporate Ability and Corporate Social Responsibility in a Developing Country: The Role of Product Involvement. J. Glob. Mark. 2012, 25, 45-56. [CrossRef]

55. Aguinis, H.; Glavas, A. What Corporate Environmental Sustainability Can Do for Industrial Organizational Psychology; Routledge: New York, NY, USA, 2013.

56. Ong, M.; Mayer, D.M.; Tost, L.P.; Wellman, N. When corporate social responsibility motivates employee citizenship behavior: The sensitizing role of task significance. Organ. Behav. Hum. Decis. Process. 2018, 144, 44-59. [CrossRef]

57. Amabile, T.M.; Hill, K.G.; Hennessey, B.A.; Tighe, E.M. The work preference inventory: Assessing intrinsic and extrinsic motivational orientations. J. Pers. Soc. Psychol. 1994, 66, 950-967. [CrossRef]

58. Schuler, R.S.; Jackson, S.E. Strategic Human Resource Management; Blackwell: Oxford, UK, 1999.

59. Aronson, K.R.; Laurenceau, J.-P.; Sieveking, N.; Bellet, W. Job Satisfaction as a Function of Job Level. Adm. Policy Ment. Health Ment. Health Serv. Res. 2005, 32, 285-291. [CrossRef]

60. Ok, C.; Park, J. Change in newcomers' job satisfaction: Met-expectations effect as a moderator. Soc. Behav. Pers. Int. J. 2018, 46, 1513-1521. [CrossRef]

61. Huang, X.; Iun, J.; Liu, A.; Gong, Y. Does participative leadership enhance work performance by inducing empowerment or trust? The differential effects on managerial and non-managerial subordinates. J. Organ. Behav. 2010, 31, 122-143. [CrossRef]

62. Steinmetz, H.; Kabst, R.; Park, Y.-K. The relationship between needs and job attitudes in South Korea and Germany. J. Manag. Psychol. 2011, 26, 623-644. [CrossRef]

63. Kim, J.; Milliman, J.; Lucas, A. Effects of CSR on employee retention via identification and quality-of-work-life. Int. J. Contemp. Hosp. Manag. 2020, 32, 1163-1179. [CrossRef]

64. Biddle, B.J. Recent developments in role theory. Ann. Rev. Social. 1986, 12, 67-92. [CrossRef]

65. Supanti, D.; Butcher, K. Is corporate social responsibility (CSR) participation the pathway to foster meaningful work and helping behavior for millennials? Int. J. Hosp. Manag. 2019, 77, 8-18. [CrossRef]

66. Kunz, J. Corporate Social Responsibility and Employees Motivation-Broadening the Perspective. Schmalenbach Bus. Rev. 2020, 72, 159-191. [CrossRef]

67. Youn, H.; Lee, K.; Lee, S. Effects of corporate social responsibility on employees in the casino industry. Tour. Manag. 2018, 68, 328-335. [CrossRef]

68. Børing, P. The relationship between firm productivity, firm size and CSR objectives for innovations. Eurasian Bus. Rev. 2019, 9, 269-297. [CrossRef]

69. Xiao, S.; Oh, K.-S. Unraveling the underlying mechanisms of new product development in high-technology emerging-market multinationals. Manag. Decis. 2019, 59, 68-83. [CrossRef]

70. Youn, H.; Hua, N.; Lee, S. Does size matter? Corporate social responsibility and firm performance in the restaurant industry. Int. J. Hosp. Manag. 2015, 51, 127-134. [CrossRef]

71. Madden, L.; McMillan, A.; Harris, O. Drivers of selectivity in family firms: Understanding the impact of age and ownership on CSR. J. Fam. Bus. Strat. 2020, 11, 100335. [CrossRef]

72. Hayes, A.F. Introduction to Mediation, Moderation, and Conditional Process Analysis: A Regression-Based Approach; Guilford Publications: New York, NY, USA, 2017; pp. 120-141.

73. Khan, A.; Latif, F.; Jalal, W.; Anjum, R.; Rizwan, M. The Impact of Rewards \& Corporate Social Responsibility (CSR) On Employee Motivation. Int. J. Hum. Resour. Stud. 2014, 4, 70. [CrossRef]

74. Malek, K.; Kline, S.F.; DiPietro, R. The impact of manager training on employee turnover intentions. J. Hosp. Tour. Insights 2018, 1, 203-219. [CrossRef]

75. Adetunji, O.J.; Ogbonna, I.G. Corporate social responsibility as a recruitment strategy by organisations. Int. Rev. Manag. Bus. Res. 2013, 2, 313-319.

76. Alrousan, R.M.; Bader, M.A.; Abuamoud, I. Stakeholders approach in influencing corporate social responsibility: A case study at two hotels in Jordan. Int. J. Tour. Policy 2015, 6, 17. [CrossRef]

77. Lee, S.; Park, S.-Y. Do socially responsible activities help hotels and casinos achieve their financial goals? Int. J. Hosp. Manag. 2009, 28, 105-112. [CrossRef] 
78. Efendi, S.; Rahardja, E. The role of intellectual capital, intrinsic motivation, and competence on service performance: Empirical Studies at Jakarta private universities. Int. J. Sci. Soc. 2021, 3, 170-185. [CrossRef]

79. Walls, P.J. Investing in human capital: Achieving organizational competitiveness through gamification. ENDLESS Int. J. Future Stud. 2021, 4, 1-7. [CrossRef]

80. Werner, S.; Balkin, D. Strategic Benefits: How Employee Benefits Can Create a Sustainable Competitive Edge; J, Total. Reward: Scottsdale, AZ, USA, 2021.

81. Allen, N.J.; Meyer, J.P. Affective, Continuance, and Normative Commitment to the Organization: An Examination of Construct Validity. J. Vocat. Behav. 1996, 49, 252-276. [CrossRef] [PubMed] 